\title{
Survival of Staphylococcus aureus in lakewater monitored by flow cytometry
}

\author{
Julian P. Diaper and Clive Edwards \\ Author for correspondence: Clive Edwards. Tel: +4451794 4405. Fax: + 44517086502 .
}

Department of Genetics and Microbiology, Life Sciences Building, Crown Street, The University, Liverpool,

L69 3BX, UK
The ability of flow cytometry to detect and enumerate viable bacteria during survival in a lakewater microcosm was assessed using Staphylococcus aureus as a model organism. Counts of colony-forming units (c.f.u.) on nutrient agar were not significantly different from those obtained by flow cytometric detection of rhodamine 123 stained bacteria and there was no evidence for a viable but nonculturable state using these methods. However c.f.u. were significantly lower when estimated using mannitol salts agar compared with nutrient agar. S. aureus was also enumerated immunofluorescently after staining with FITC-IgG. There was no significant difference between the population estimated immunofluorescently and by acridine orange direct counting, and unlike estimations of viability, only slight reductions in total cell numbers were observed. Changes in the protein and nucleic acid content of $\mathbf{S}$. aureus during survival were also measured by flow cytometry to investigate any potential heterogeneity arising within the starved population. Flow cytometric determinations were found to correlate significantly with their respective chemical determinations. These results demonstrate the ability of flow cytometry to detect viable bacteria during starvation and to study changes in macromolecular content. They also illustrate the importance of using appropriate methods for the detection of viable bacteria in environmental samples.

Keywords: flow cytometry, Stapbylococcus aureus, starvation survival, cell enumeration

\section{INTRODUCTION}

Direct methods for the detection of target bacteria in environmental samples are of increasing importance in microbial ecology. This is particularly so now because it is believed that some bacteria can enter a viable but nonculturable state (Roszak \& Colwell, 1987). Flow cytometry (FCM) combines the advantages of microscopy and biochemical analysis for the measurement of physical or chemical characteristics of individual cells as they move in a fluid stream past optical or electronic sensors (Muirhead et al., 1985). The technique has found widespread applications for studying eukaryotic cells (Mackensie \& Pinder, 1987), but applications for studying bacteria are more limited. Even so, FCM has been successfully applied to studies of the bacterial cell cycle

Abbreviations: AODC, acridine orange direct count; FCM, flow cytometry; FITC, fluorescein isothiocyanate; MSD, minimum significant difference; NALS, narrow-angle light scatter; PI, propidium iodide; PMT, photomultiplier tube; Rh123, rhodamine 123; WALS, wide-angle light scatter.
(Skarstad et al., 1983) and enumeration of bacteria in pure cultures (Pinder et al., 1990), and its potential as a tool for use in microbial ecology has been recognized (Burkill, 1987; Edwards et al., 1992a, b). FCM has been used to detect target bacteria in environmental samples by several workers using both immunofluorescence (Tyndall $e t$ al., 1985) and 16s rRNA probes (Amann et al., 1990). However neither of these methods is able to specifically detect viable bacteria. Recent work has demonstrated that rhodamine 123 ( $\mathrm{Rh} 123$ ), which is taken up in response to membrane potential (Kaprelyants \& Kell, 1992) can be used as a dye to detect and enumerate viable bacteria by FCM after growth in laboratory media (Diaper et al., 1992). However its ability to detect viable bacteria in environmental samples has not yet been demonstrated.

The aim of this work was to assess the ability of FCM to detect and enumerate viable bacteria during survival in a lakewater microcosm. Stapbylococcus aureus was chosen as a model organism because previous work had shown that it was possible to differentiate between viable and dead cells using Rh123 (Diaper tt al., 1992) and cells can also be 
immunofluorescently detected by FCM after staining with FITC-IgG, even in heterogeneous bacterial populations (Edwards et al., 1992a). S. aureus has also been isolated from stormwater and it has been suggested that the occurrence of this and other pathogenic bacteria in stormwater presents a potential health hazard (O'Shea \& Field, 1992). Chemical determinations of cellular protein and nucleic acids were compared with FCM determinations after staining with the appropriate fluorochrome to assess the ability of FCM to detect changes in macromolecular content of bacteria as well as to measure the heterogeneity within the population during survival.

\section{METHODS}

Bacterial strains and culture conditions. The Cowan 1 strain of Stapbylococcus aureus was a gift from Dr C. J. Duggleby (PHLS CAMR, Porton Down, Salisbury, UK). It was maintained on nutrient broth (Lab M) solidified with $1.5 \%$ (w/v) agar (Lab $\mathrm{M})$. Colony-forming units (c.f.u.) were calculated after incubation of appropriately diluted samples at $37^{\circ} \mathrm{C}$ on either nutrient agar for $24 \mathrm{~h}$ or mannitol salts agar (MSA; Oxoid CM 85) for $48 \mathrm{~h}$.

Inoculation of microcosms. Cultures of $S$. aureus were grown for $18 \mathrm{~h}$ at $37^{\circ} \mathrm{C}$ in nutrient broth that had been filtered by passage three times through a Durapore membrane filter of $(1.22 \mu \mathrm{m}$ pore size (Millipore). The cells were washed once with autoclaved lakewater (Windermere, English Lake District), filtered through a $0 \cdot 1 \mu \mathrm{m}$ pore size nitrocellulose membrane filter (Sartorius), and inoculated into filtered autoclaved lakewater at cell densities of approximately $10^{9}$ bacteria $\mathrm{ml}^{-1}$, or $10^{7}$ bacteria $\mathrm{ml}^{-1}$. The microcosms were incubated at $12^{\circ} \mathrm{C}$ $\left( \pm 1^{\circ} \mathrm{C}\right)$ for $21 \mathrm{~d}$ and samples taken at regular intervals.

Estimation of total numbers of bacteria. The acridine orange direct counting (AODC) method described by Fry (1990) was used to estimate the total number of bacteria in microcosm samples.

Preparation of bacteria for FCM analysis. Viable bacterial numbers were estimated by FCM after staining with Rh123 (Sigma) using the method of Diaper et al. (1992). Cell suspension $(1 \mathrm{ml})$ was washed with phosphate-buffered saline (PBS) and resuspended in $5 \mathrm{ml}$ PBS that contained $5 \mu \mathrm{g} \mathrm{Rh} 123 \mathrm{ml}^{-1}$. The bacteria were then incubated at $37^{\circ} \mathrm{C}$ for $30 \mathrm{~min}$ and washed three times with PBS before analysis by FCM.

S. aureus cells were also enumerated by FCM after staining with fluorescein-isothiocyanate-conjugated human IgG (FITC-IgG; Sigma). Samples $(1 \mathrm{ml})$ were washed with PBS, resuspended in $900 \mu \mathrm{l} \mathrm{PBS}$ containing 3\% (w/v) BSA, and $100 \mu \mathrm{l}$ FITC-IgG $\left(150 \mu \mathrm{g} \mathrm{ml}^{-1}\right)$ was added to the cell suspension, which was then incubated at room temperature for $30 \mathrm{~min}$ and washed three times in PBS.

Formaldehyde-fixed cells were stained with fluorescein isothiocyanate (FITC) using the method of Allman et al. (1990). Cell suspensions $(1 \mathrm{ml})$ were washed twice with $0 \cdot 1 \mathrm{M}$ Tris/ $\mathrm{HCl}$ buffer $\mathrm{pH} 7 \cdot 6$ and then resuspended in $1 \mathrm{ml} 0 \cdot 1 \mathrm{M}$ Tris/HCl buffer $\mathrm{pH} 9$ containing $2.6 \mathrm{mM}$ FITC (Sigma). Cells were incubated overnight at $4{ }^{\circ} \mathrm{C}$, washed three times with $0.1 \mathrm{M}$ Tris/ $\mathrm{HCl} \mathrm{pH} 7.6$ and resuspended in $0.1 \mathrm{M}$ Tris/ $\mathrm{HCl} \mathrm{pH} 7 \cdot 6$ containing $0.9 \% \mathrm{NaCl}$.

The method used to stain bacteria with propidium iodide (PI) was based on that of Miller \& Quales (1980). An ethanol-fixed cell suspension $(1 \mathrm{ml})$ was washed twice in phosphate-buffered saline (PBS) and resuspended in $1 \mathrm{ml}$ PBS containing $50 \mu \mathrm{g}$ $\mathrm{PI} \mathrm{m} l^{-1}$. The cells were incubated for $10 \mathrm{~min}$ at $37^{\circ} \mathrm{C}$ and then washed once with PBS.

Bacteria were stained with Hoechst 33342 (Sigma) using the method of van Dilla et al. (1982). Ethanol-fixed cells were washed twice and resuspended in Tris/ $\mathrm{HCl}$ buffer $(10 \mathrm{mM}$

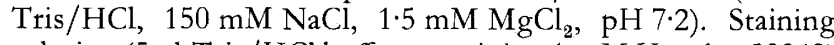
solution $(5 \mu \mathrm{l}$ Tris/ $\mathrm{HCl}$ buffer containing $1 \mathrm{mM}$ Hoechst 33342$)$ was added to the cell suspension, which was then incubated at room temperature for $30 \mathrm{~min}$. The stained cells were washed once with Tris/ $\mathrm{HCl}$ buffer.

FCM. A Skatron Argus 100 instrument (Skatron Ltd, PO Box 34, Newmarket, Suffolk, UK) was used. Sheath fluid was prepared by filtering distilled water three times through a $0.22 \mu \mathrm{m}$ pore size nitrocellulose membrane filter (Sartorius). The sheath fluid pressure was set at $1 \mathrm{kPa} \mathrm{cm}^{-1}$ and the sample flow rate was set between $1 \mu \mathrm{l}$ and $10 \mu \mathrm{min}^{-1}$.

Changes in light-scattering properties of the cells were monitored using light at a wavelength of between 395 and $440 \mathrm{~nm}$. Narrow-angle light scatter (NALS) was used as an indicator of cell size and wide-angle $\left(90^{\circ}\right)$ light scatter (WALS) was used as an indicator of cell 'granularity' (Burkill, 1987). NALS was detected using a gain of 16 and a PMT setting of $450 \mathrm{~V}$, and WALS employed a gain of 32 and a PMT setting of $640 \mathrm{~V}$. FITC and Rh123 fluorescence was detected using an excitation wavelength of $470-495 \mathrm{~nm}$, a stopband of $510 \mathrm{~nm}$ and emission at $520-560 \mathrm{~nm}$; PI fluorescence was detected using an excitation of $520-560 \mathrm{~nm}$, a stopband of $570 \mathrm{~nm}$ and emission at $590 \mathrm{~nm}$; Hoechst 33342 fluorescence was detected using an excitation of $395-400 \mathrm{~nm}$, a stopband of $460 \mathrm{~nm}$ and emission at $470 \mathrm{~nm}$.

Cells were detected by the flow cytometer using their NALS signal; the fluorescent signal was then gated using this parameter. FITC-labelled bacteria were detected using a gain of 32 and a PMT setting of $660 \mathrm{~V}$, PI-labelled bacteria were detected using a gain of 8 and a PM'T setting of $550 \mathrm{~V}$ and Hoechst 33342-labelled bacteria were detected using a gain of 4 and a PMT of $600 \mathrm{~V}$. Rh123- and FITC-IgG-labelled bacteria were detected using a logarithmic gain and a PMT setting of $650 \mathrm{~V}$.

Several controls were used throughout these experiments to examine possible interference from autofluorescence and nonspecific binding. FITC-, PI- and Hoechst-33342-stained samples were all compared with unstained samples. Samples treated with gramicidin S were used as controls for Rh123-stained samples and Escherichia coli and Pseudomonas fuorescens were used initially as negative controls for FITC-IgG-stained cells. Both of these controls had fluorescence distributions of less than channel number 50. The numbers of Rh123-stained bacteria $\mathrm{ml}^{-1}$ and FITC-IgG stained bacteria $\mathrm{ml}^{-1}$ were therefore calculated from the area of the fluorescence histogram above channel 50 . The detection limit of FITC-IgG-stained cells was estimated from a serial dilution of a $S$. aureus culture. The number of FITC-IgGstained bacteria detected by the flow cytometer in the different dilutions was compared with a control sample and c.f.u. values. The detection limit was defined as the lowest dilution in which the number of bacteria detected was significantly greater than that in the control.

Fluorescent beads of $2 \mu \mathrm{m}$ diameter (CV $<2 \%$; Polyscience) were used to focus the flow cytometer before use. The beads were detected using light at a wavelength of between 470 and 495 , a PMT setting of $500 \mathrm{~V}$ and a gain of $2 \cdot 00$. The NALS peak channel number of the beads was between 122 and 131 .

Biochemical determinations. Total cellular protein, DNA and RNA were estimated chemically from $1 \mathrm{ml}$ samples. A high 
density of bacteria was required for accurate chemical determinations; therefore samples taken during the survival of $S$. aureus in microcosms inoculated to initial cell densities of $10^{9}$ bacteria $\mathrm{ml}^{-1}$ were used. Bacteria were pelleted and resuspended in $1 \mathrm{ml} 0 \cdot 1 \mathrm{M}$ Tris $/ \mathrm{HCl} \mathrm{pH} 7 \cdot 6$. Total protein was estimated using the biuret method after extraction with $1 \mathrm{M}$ $\mathrm{NaOH}$ and using similarly treated bovine serum albumin (BSA) as a protein standard (Herbert $e t$ al., 1971). Total nucleic acids were extracted with perchloric acid; RNA was estimated by the orcinol method using baker's yeast RNA (Sigma) as a standard; and DNA was estimated by the diphenylamine method using calf thymus DNA (Sigma) as a standard (Herbert et al., 1971). The amounts of cellular protein, RNA and DNA estimated chemically were expressed as $\mathrm{mg}\left(10^{9} \text { bacteria }\right)^{-1}$.

Statistical analysis. The data shown represent the means of three independent measurements. Survival experiments were also repeated and the graphs presented are typical of up to three experiments. Correlation and analysis of variance were performed using the Minitab computer package (Ryan et al., 1985). All bacterial counts were transformed by $\log _{10} x$ to ensure normality of distribution and homogeneity of variances. Minimum significant difference (MSD) was calculated by the TukeyKramer method (Sokal \& Rohlf, 1981). A probability of $P<0.05$ was considered significantly different.

\section{RESULTS}

\section{Detection and enumeration of $S$. aureus stained with FITC-IgG by FCM}

After staining with FITC-IgG the fluorescence distribution of the $S$. aureus population could be detected with a peak channel of 95 and a $\mathrm{CV}$ of $18 \%$. Multiparametric analysis of fluorescence indicated little heterogeneity of labelled cells; large cells had a higher fluorescence than small cells (Fig. 1a). Pseudomonas fuorescens and Escherichia coli were used as negative controls and both gave a fluorescence distribution of below channel 50 (result not shown). Channel 50 was therefore defined as the threshold level to distinguish between FITC-IgG-labelled and unlabelled cells. The ability of the flow cytometer to detect and enumerate $S$. aureus after staining with FITCIgG was then investigated using different cell densities of S. aureus in PBS. Fig. 1(b) compares cell numbers determined by FCM with c.f.u. determined from nutrient agar plates. There was no significant difference between FCM counts and those estimated from c.f.u. after growth in nutrient broth. The detection limit was below $5 \times 10^{3}$ bacteria $\mathrm{ml}^{-1}$.

The ability of FCM to detect FITC-IgG-stained S. aureus was employed as a method to directly enumerate the total number of intact cells of $S$, aureus during survival in a lakewater microcosm.

\section{FCM detection of viable $S$. aureus during survival in a freshwater microcosm}

The aim of this experiment was to assess the ability of FCM to measure viability of bacteria during prolonged starvation in a lakewater microcosm. FCM-determined viable cell numbers (Rh123-stained) were compared with c.f.u. determined on nutrient agar or mannitol salts agar
(MSA). Total numbers of bacteria were determined microscopically by AODC and by FCM after staining with FITC- $\operatorname{Ig} G$. After inoculation at an initial cell density of $1 \times 10^{7}$ bacteria $\mathrm{ml}^{-1}$, there was a rapid reduction in the viability of the culture as estimated by c.f.u. (Fig. 2). This reduction was greater when numbers were calculated from c.f.u. on MSA than on nutrient agar. Using MSA no culturable bacteria were detected after day 7; however viable bacteria could still be detected after growth on nutrient agar up to day 21 (Fig. 2). The population of viable bacteria estimated by FCM enumeration of Rh123stained bacteria also fell during the experiment, and there was no significant difference between the population estimated by the FCM after staining with Rh123 and that estimated from c.f.u. on nutrient agar up to day 14 (Fig. 2). After day 14 the numbers of live bacteria fell below the FCM detection limit. Peak channel numbers of Rh123stained viable bacteria remained relatively constant; the gradual loss in viability seen during the first $14 \mathrm{~d}$ was represented by a reduction in the area of the histogram above channel 50 (Fig. 3a, b). Treatment with gramicidin
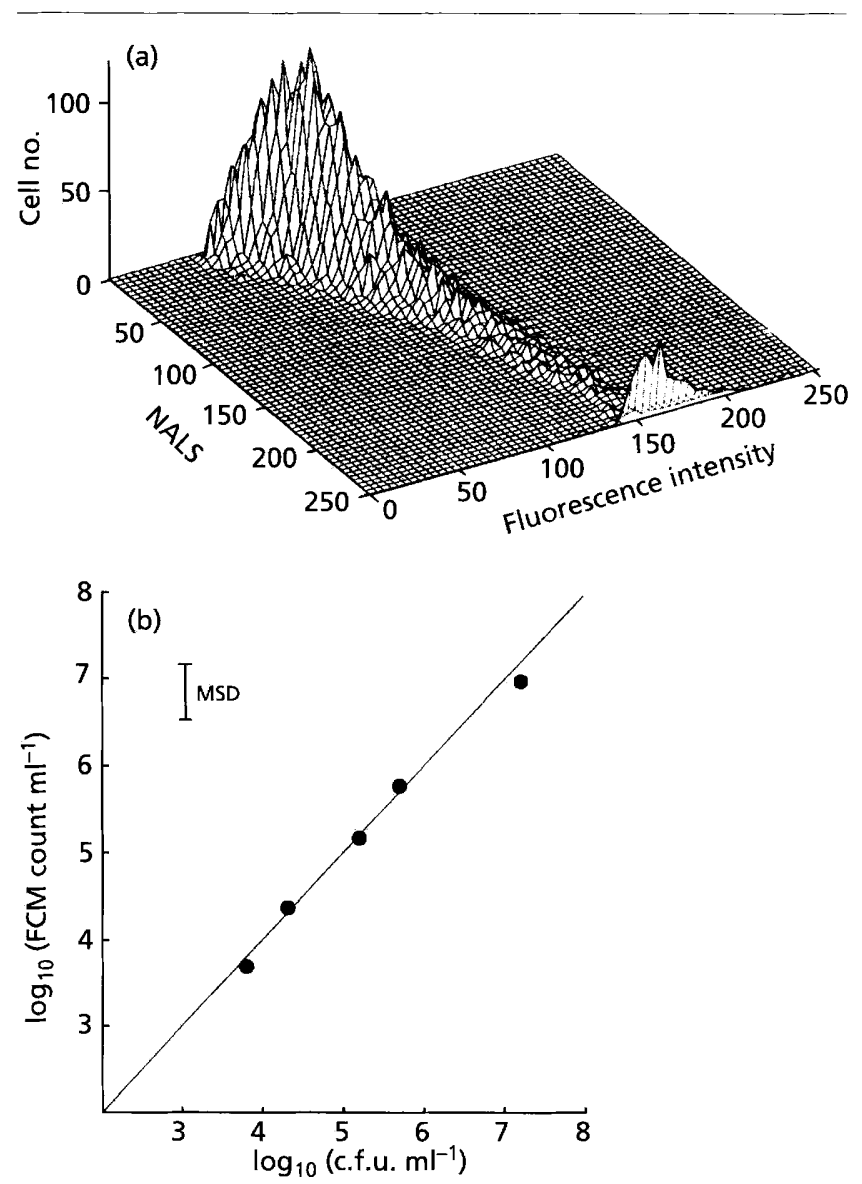

Fig. 1. Detection of FITC-IgG-stained $S$. aureus by FCM. (a) Multiparameter plot of narrow-angle light scatter (NALS) versus fluorescence, with the relative numbers of bacteria shown for each. (b) Relationship between c.f.u. determined on nutrient agar and FCM-determined counts of FITC-IgG-stained bacteria. The ideal relationship is represented by the line; 0 , actual values. Correlation coefficient $\bar{r}=0.991$. 


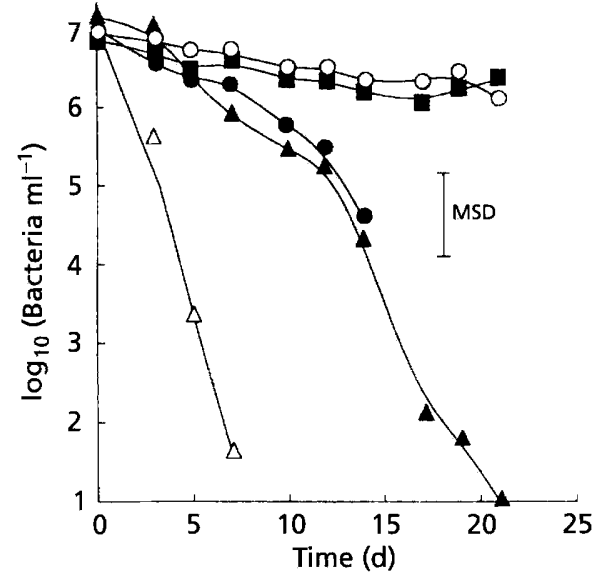

Fig. 2. Survival of S. aureus in a lakewater microcosm at $12^{\circ} \mathrm{C}$ $\left( \pm 1{ }^{\circ} \mathrm{C}\right)$ after inoculation at an initial cell density of approx. $10^{7}$ c.f.u. $\mathrm{ml}^{-1}: \triangle$, c.f.u. on mannitol salts agar; $\Delta$, c.f.u. on nutrient agar; $\mathbf{O}$, number of Rh123-stained cells estimated by FCM; , AODC; $O$, number of FITC-IgG-stained cells estimated by FCM.

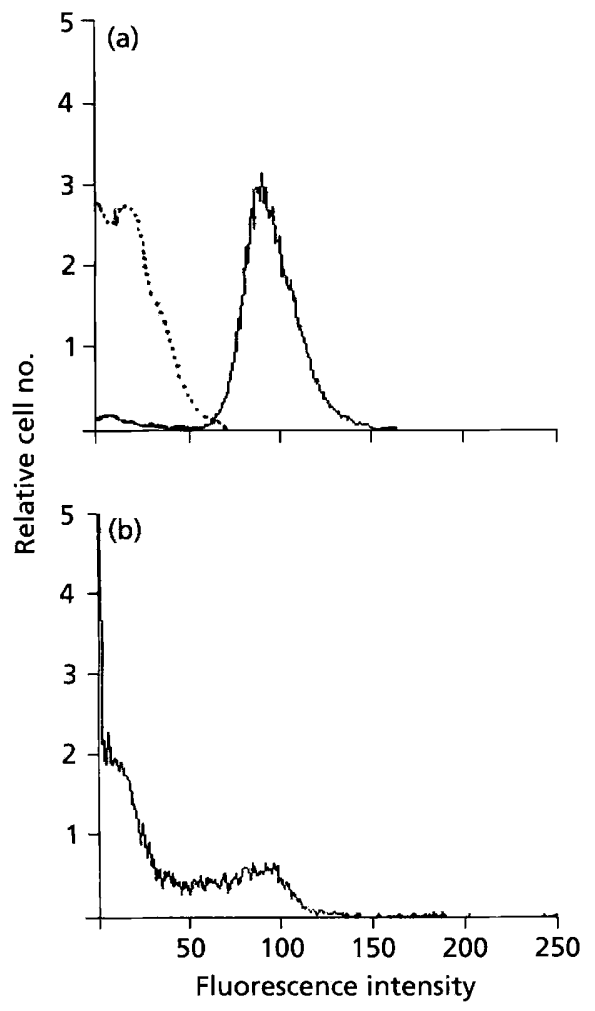

Fig. 3. Examples of fluorescence histograms of Rh123-stained S. aureus during survival in a lakewater microcosm at $12{ }^{\circ} \mathrm{C}$ $\left( \pm 1^{\circ} \mathrm{C}\right)$ after inoculation at an initial cell density of approximately $10^{7}$ c.f.u. $\mathrm{ml}^{-1}$. (a) Day 0 (broken line represents cells treated with gramicidin $S$ ); (b) day 12 .

$S$ reduced the histogram to below channel 50 (Fig. 3a). In contrast to the reduction in the viability of the culture, there was no significant reduction in the total bacterial

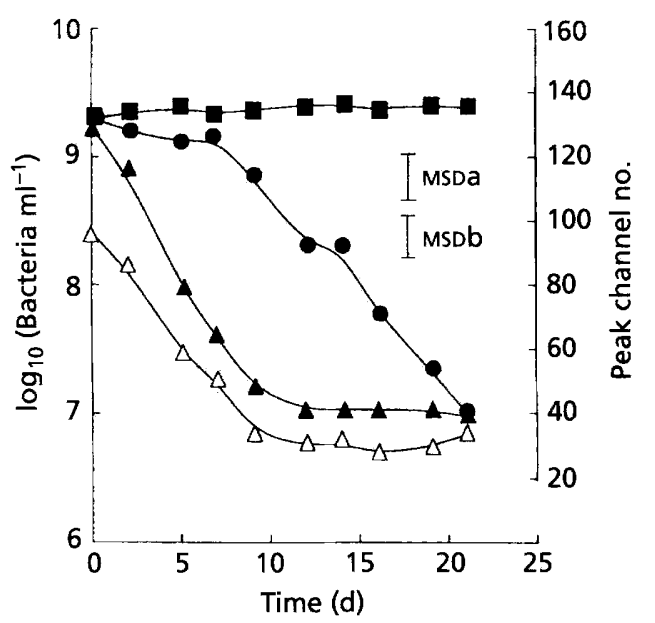

Fig. 4. Survival of $S$. aureus in a lakewater microcosm at $12{ }^{\circ} \mathrm{C}$ $\left( \pm 1^{\circ} \mathrm{C}\right)$ after inoculation at an initial cell density of approximately $10^{9}$ c.f.u. $\mathrm{ml}^{-1}$. O. C.f.u. on nutrient agar; $\mathbf{\square}$, AODC; $\triangle$, narrow-angle light-scatter (NALS) peak channel number; $\boldsymbol{A}$, wide-angle light-scatter (WALS) peak channel number. MSDa, minimum significant difference of c.f.u. and AODC; MSDb, minimum significant difference of narrow- and wide-angle light scatter.

number calculated from AODC or after enumeration of FITC-IgG-labelled bacteria by FCM (Fig. 2), implying that intact cells were present.

\section{Changes in light-scattering properties and total amounts of cellular proteins, RNA and DNA of $S$. aureus during starvation}

To assess the ability of FCM to monitor changes in the macromolecular content of $S$. aureus, amounts of protein, RNA and DNA were determined by chemical methods and compared with FCM determinations of bacteria stained with appropriate fluorochromes. A high cell density was required for accurate chemical determinations; therefore $S$. aureus was inoculated to an initial cell density of $2 \cdot 1 \times 10^{9}$ bacteria $\mathrm{ml}^{-1}$. Viability, monitored by c.f.u. on nutrient agar, remained relatively constant for the first $7 \mathrm{~d}$; it then dropped to $1.02 \times 10^{7} \mathrm{ml}^{-1}$ by day 21 (Fig. 4). Total numbers of bacteria as measured by AODC remained at approximately $2 \times 10^{9} \mathrm{ml}^{-1}$ throughout the $21 \mathrm{~d}$ duration of the experiment.

Although there was no apparent loss of viability during the first week of the experiment, there were rapid reductions in the NALS and WALS of the cells; these two parameters then remained constant for the remainder of the experiment (Fig. 4). These reductions in the lightscattering properties of the bacteria could not be correlated with changes in the size of the cells when compared with electron micrographs (results not shown). Changes in WALS did correlate with changes in cellular RNA $(r=0.979)$.

Both FCM and chemical determinations showed reductions in DNA, RNA and protein during the survival experiment. These reductions in fluorescence gave a 


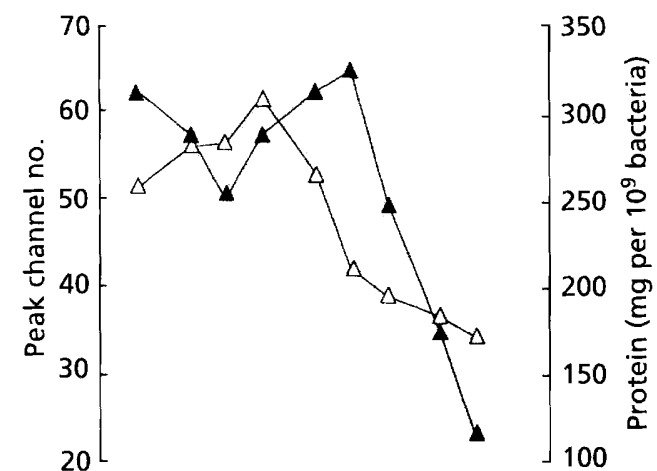

(a)
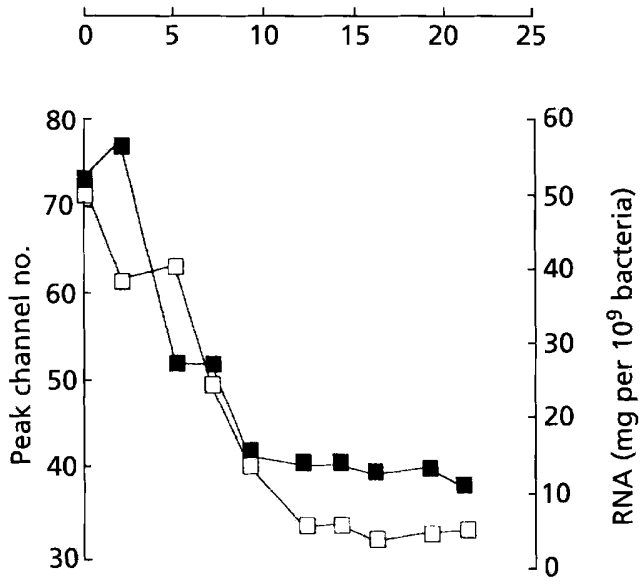

(b)
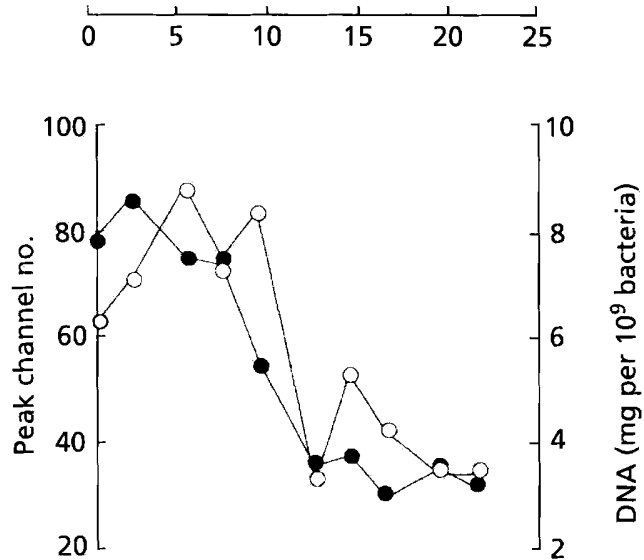

(c)

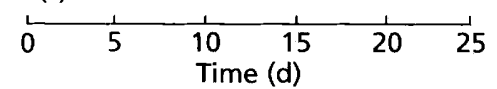

Fig. 5. Changes in macromolecular content of $S$. aureus during survival in a lakewater microcosm at $12^{\circ} \mathrm{C}\left( \pm 1^{\circ} \mathrm{C}\right)$ after inoculation at an initial cell density of approximately $10^{9}$ c.f.u. $\mathrm{ml}^{-1}$. (a) Relationship between peak channel number of FITC-stained cells $(\boldsymbol{\Delta})$ and cellular protein estimated by the biuret method $(\triangle)$. Correlation coefficient $r=0.653$. (b) Relationship between peak channel number of PI-stained cells (ם) and cellular RNA estimated by the orcinol method ( $\square$ ). Correlation coefficient $r=0.88$. (c) Relationship between peak channel number of Hoechst-33342-stained cells $(\bullet)$ and cellular DNA estimated by the diphenylamine method (O). Correlation coefficient $r=0.8$.
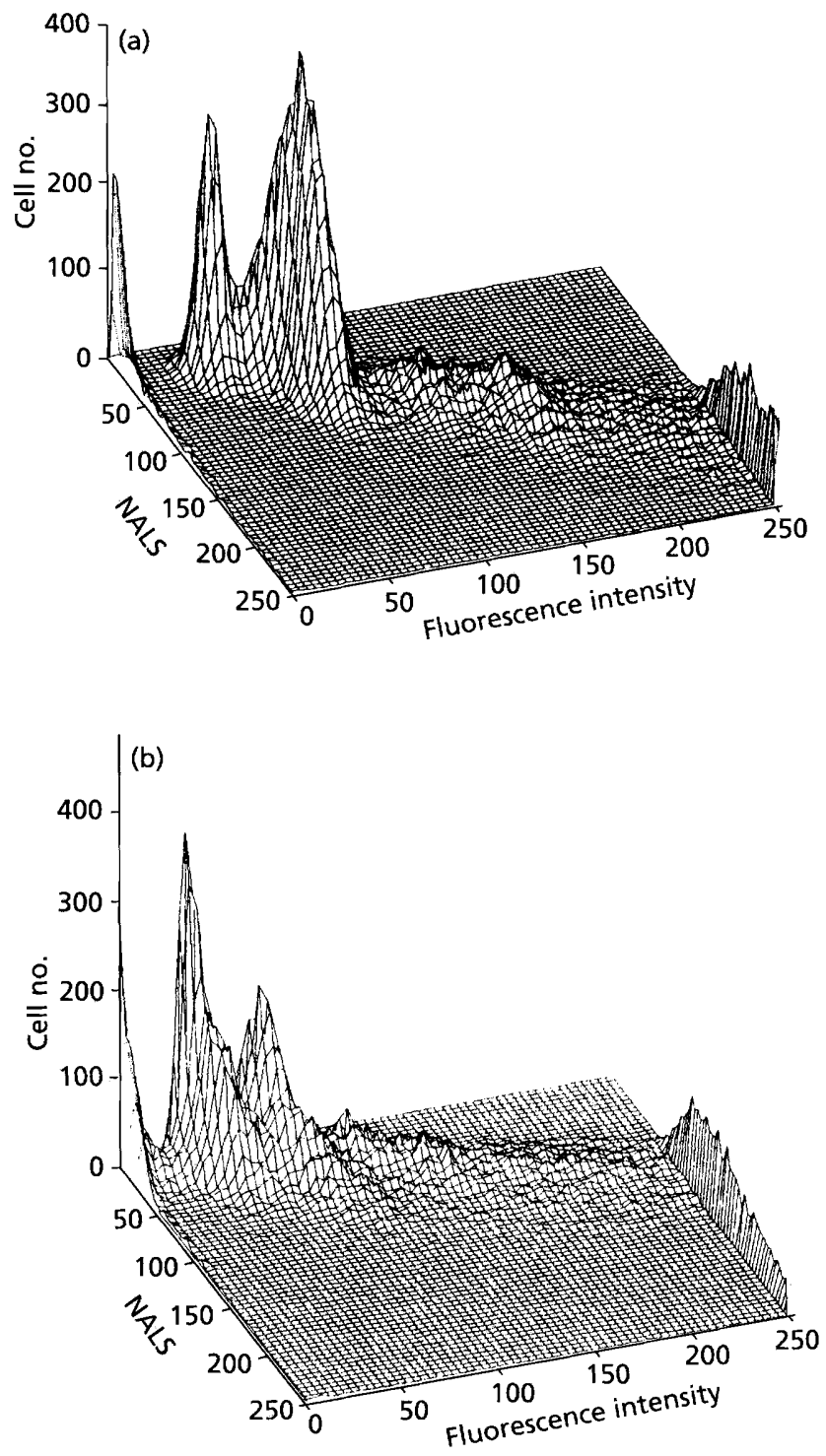

Fig. 6. Examples of FCM histograms of $S$. aureus stained with Hoechst 33342 during survival in a lakewater microcosm at $12^{\circ} \mathrm{C}\left( \pm 1^{\circ} \mathrm{C}\right)$ after inoculation at an initial cell density of approximately $10^{9}$ c.f.u. $\mathrm{ml}^{-1}$. (a) Day 0; (b) day 19.

significant correlation between protein and RNA content estimated by the chemical methods and the peak fluorescent channel number from histograms of FITC- and PIstained bacteria (Fig. 5a, b).

Multiparameter analysis using isometric plots did not reveal any changes in heterogeneity of FITC- or PIstained cells during starvation. A comparison of cellular DNA estimated biochemically by the diphenylamine method and cellular fluorescence measured by FCM after staining with Hoechst 33342 also gave a significant correlation between peak channel number and estimated amounts of DNA (Fig. 5c). In addition, after staining cells from day 0 with Hoechst 33342, isometric plots revealed two prominent populations of bacteria plus several minor ones of increasing fluorescence. The major fluorescent 
peaks had a channel number of 83 and the minor peak had a channel number of 42 (Fig. 6a). During the course of the experiment a shift occurred whereby the more fluorescent of the two populations reduced in area while the population with the lower fluorescent peak channel number increased in area (Fig. 6b). There were still however cells at day 21 with a higher fluorescence than that of the main population. In addition, the reductions in NALS meant that by day 21 , there was increased heterogeneity whereby cells displaying similar lightscattering properties had a range of different fluorescence intensities.

\section{DISCUSSION}

Using dilutions of an $S$. aureus culture, the potential of FCM to enumerate a bacterial population using immunofluorescence was demonstrated by the significant correlation between cell numbers detected after staining with FITC-IgG and cell numbers estimated from c.f.u. Similar detection of immunologically stained bacteria by FCM has been demonstrated by other workers (Donnelly \& Baigent, 1986; Tyndall et al., 1985) but these reports have been qualitative rather than quantitative; therefore there is scope for applying FCM for the enumeration as well as identification of target bacteria from a range of habitats. Reports of the ability of FCM to enumerate bacteria have been limited to the use of stains such as ethidium bromide (Pinder et al., 1990) and similar detection limits to those described here were reported. More sensitive detection of Cryptosporidium oocysts was achieved using FCM by Vessy et al. (1991) after concentration by filtration. Therefore by concentration of samples it should be possible to enumerate bacterial cells present at levels as low as $10^{1}-10^{2} \mathrm{ml}^{-1}$.

Monitoring numbers of $S$. aureus during survival in lakewater revealed a number of interesting observations. The c.f.u. on nutrient agar and numbers of Rh123-stained bacteria correlated as indicators of viability and there was no indication of non-culturability. The difference between total counts obtained by AODC and c.f.u. after growth on nutrient agar observed in our experiments represents the difference between live and dead cells. In contrast, a comparison of c.f.u. after growth on MSA with the Rh123 numbers (in the absence of c.f.u. on nutrient agar) could be taken as evidence for the adoption of a viable but nonculturable (VBNC; Roszak \& Colwell, 1987) state by $S$. aureus. It is suggested however that the VBNC state in this case was caused by an inability of $S$. aureus to grow on MSA after a period of starvation and not an inability to grow on artificial media per se. It therefore follows that reports of the VBNC state in other bacteria may merely reflect the inability of bacteria to grow on particular media after being subjected to stress (Edwards, 1993).

Although the number of cells detected immunofluorescently correlated to c.f.u. in preliminary experiments, during survival of $S$. aureus in lakewater no correlation was observed. It is known that immunofluorescent detection of bacteria does not necessarily reflect their viability (Bohlool \& Schmidt, 1980) and therefore this method can only be used to detect the total number of a species present and gives no indication of the viability of the target population.

The ability of FCM to analyse single cells and therefore measure heterogeneity within a bacterial population was tested by measuring changes in protein, RNA and DNA during survival of a bacterial culture. The observed reduction in both NALS and WALS did not correlate with either cell size or viability. It is generally accepted that the intensity of NALS is related to cell size (Burkill, 1987); however Allman et al. (1992), whilst studying the light-scattering properties of different bacterial species, found that several gave a light-scatter signal out of proportion to their size and suggested that this might be explained by other properties of light-scatter such as refractive index. This may also be true for the $S$. aureus studies described here. There was a rapid reduction in the WALS which did not correlate with the 'granularity' of the cells as expected (Burkill, 1987) but its correlation with RNA levels may suggest that WALS can act as an indicator of the metabolic potential of bacteria. However, since the appearance of ghosts in the culture by day 12 was not detected using WALS it would be difficult to obtain any useful information from this parameter alone. This would also be true for NALS, although it can be observed from both these parameters that stressed bacteria (i.e. during survival in a lakewater microcosm) have lower NALS and WALS than those growing in nutrient broth. The heterogeneity observed from the FCM data was probably due to the individual cells being at different stages of the cell cycle at the onset of starvation (Kell et al., 1991).

Correlation between FITC fluorescence and biochemical determination of cellular protein demonstrated the ability of FCM to rapidly detect changes in cellular protein during the survival of a bacterial culture. A similar relationship between FITC fluorescence and cellular protein was also observed by Allman et al. (1990) during growth of Azotobacter vinelandii, and reduction in cellular protein during the starvation of bacteria has been documented elsewhere (Kjelleberg et al., 1987). It has also been suggested that reduction in cellular protein may be related to the viability and vitality of the culture (Martin, 1992), but as with the data obtained from the lightscattering properties of the cells the apparent inability of FCM to specifically detect changes in the fluorescence of viable bacteria after FITC staining limits any additional information obtained by analysing individual cells as opposed to the population as a whole.

The correlation between PI fluorescence and cellular RNA measured by the orcinol method similarly demonstrated the potential of FCM to detect changes in cellular RNA. Although PI has been used previously to study the nucleic acid content of bacteria by FCM these studies used RNase-treated bacteria and measured their DNA content (Hutter \& Eipel, 1987; Miller \& Quales, 1980). There may be interference from DNA in our experiments, but preliminary work (unpublished data) showed that DNase treatment did not reduce the fluorescence of bacteria when stained with PI. Our results therefore demonstrate 
the applicability of this stain to study changes in cellular RNA. However as with both the light-scattering and FITC data the FCM was not sensitive enough to differentiate between populations of viable and dead bacteria using this method, if such differences are in fact present.

The analysis of the DNA content of $S$. aureus by FCM not only correlated with biochemical estimations but also showed several distinct populations. This ability of FCM to detect populations of bacteria with different amounts of DNA has been reported after treatment of E. coli with rifampicin (Steen et al., 1990) and after the onset of starvation of Yersinia rucketii (Thorsen et al., 1992) and has been interpreted as representing bacteria with differing numbers of chromosomes. It is possible that in our experiments the two main peaks observed represent bacteria with one and two chromosomes although the possibility of cells sticking together cannot be entirely ruled out. However if these two peaks do represent different chromosomal numbers, during the experiment the relative number of bacteria with only one chromosome increases. This may be a result of reductive division. Similar conclusions can be inferred from chemical estimations but FCM has the unique ability to demonstrate this rapidly.

Overall this work has shown that FCM has great potential for analysis of microbial populations. Validation of quantitative changes in macromolecular composition with chemical methods means that in future these cell components may be monitored by FCM. This approach is more rapid, automated, requires fewer cells for analysis than for chemical determinations and has the potential to analyse heterogeneity within populations or the cell cycle of a single species.

\section{ACKNOWLEDGEMENTS}

We would like to thank Dr C. J. Duggleby for providing the strain of $S$. aureus used in the work and the NERC for funding this work (grant number GR3 7596).

\section{REFERENCES}

Allman, R., Hann, A. C., Phillips, A. P., Martin, K. L. \& Lloyd, D. (1990). Growth of Azotobacter vinelandii with correlation of coulter cell size, flow cytometric parameters and ultrastructure. Cytometry 11, 822-831.

Allman, R., Hann, A. C., Manchee, R. \& Lloyd, D. (1992). Characterization of bacteria by multiparameter flow cytometry. I Appl Bacteriol 73, 438-444.

Amann, R. I., Binder, B. J., Olson, R. J., Chisholm, S. W., Devereux, R. \& Stahl, D. A. (1990). Combination of $16 \mathrm{~S}$ rRNA-targeted oligonucleotide probes with flow cytometry for analyzing mixed microbial populations. Appl Environ Microbiol 56, 1919-1925.

Bohlool, B. B. \& Schmidt, E. L. (1980). The immunofluorescence approach in microbial ecology. Adv Microb Ecol 4, 204-241.

Burkill, P. H. (1987). Analytical flow cytometry and its application to marine microbial ecology. In Microbes in the Sea, pp. 139-166. Edited by M. A. Sleigh. Chichester: Ellis Horwood.

Diaper, J. P., Tither, K. \& Edwards, C. (1992). Rapid assessment of bacterial viability by flow cytometry. Appl Microbiol Biotechnol 38, $268-272$. van Dilla, M. A., Langlois, R. G., Pinkel, D., Yajko, D. \& Hadley, W. K. (1982). Bacterial characterisation by flow cytometry. Science 220, 620-622.

Donnelly, C. W. \& Baigent, G. J. (1986). Method for flow cytometric detection of Listeria monocytogenes in milk. Appl Environ Microbiol 52, 689-695.

Edwards, C. (1993). The significance of in situ activity on the efficiency of monitoring methods. In Monitoring Genetically Manipulated Microorganisms in the Environment, pp. 1-25. Edited by C. Edwards. Chichester: John Wiley.

Edwards, C., Diaper, J. P., Porter, J. \& Pickup, R. (1992a). Applications of flow cytometry in bacterial ecology. In Flow Cytometry in Microbiology, pp. 121-129. Edited by D. Lloyd. London: Springer-Verlag.

Edwards, C., Porter, J., Saunders, J. R., Diaper, J., Morgan, J. A. W. \& Pickup, R. W. (1992b). Flow cytometry and microbiology. Soc Gen Microbiol Quarterly 19, 105-108.

Kaprelyants, A. S. \& Kell, D. B. (1992). Rapid assessment of bacterial viability and vitality using rhodamine 123 and flow cytometry. J Appl Bacteriol 72, 410 422.

Kell, D. B., Ryder, H. M., Kaprelyants, A. S. \& Westerhoff, H. V. (1991). Quantifying heterogeneity: flow cytometry of bacterial culture. Antonie Leenwenboek 60, 145-422.

Kjelleberg, S., Hermansson, M., Marden, P. \& Jones, G. W. (1987). The transient phase between growth and nongrowth of heterotrophic bacteria, with emphasis on the marine environment. Annu Rev Microbiol 41, 25-49.

Fry, J. C. (1990). Direct methods and biomass estimation. Methods Microbiol 22, 41-85.

Herbert, D., Phillips, P. J. \& Strange, R. E. (1971). Chemical analysis of microbial cells. Methods Microbiol 5B, 210-344.

Hutter, K.-J. \& Eipel, H. E. (1979). Microbial determinations by flow cytometry. J Gen Microbiol 113, 369-375.

Mackensie, N. M. \& Pinder, A. C. (1987). Flow cytometry and its applications in veterinary medicine. Res $V$ et Sci 42, 131-139.

Martin, A. (1992). Physiology, molecular biology and applications of the bacterial starvation response. J Appl Bacteriol Symp Suppl 73, 49S-57S.

Miller, J. S. \& Quales, J. M. (1980). Flow cytometric identification of microorganisms by dual staining with FITC. Cytometry 11, 667-675.

Muirhead, K. A., Horan, P. K. \& Poste, G. (1985). Flow cytometry: present and future. Biotecbnology 3, 337-356.

O'Shea, M. L. \& Field, R. (1992). An evaluation of bacterial standards and disinfection practices used for the assessment and treatment of stormwater. Adv Appl Microbiol 37, 21-40.

Pinder, A. C., Purdy, P. W., Poulter, S. A. G. \& Clark, D. C. (1990). Validation of flow cytometry for rapid enumeration of bacterial concentrations in pure cultures. J Appl Bacteriol 69, 92-100.

Roszak, D. B. \& Colwell, R. R. (1987). Survival strategies of bacteria in the natural environment. Microbiol Rev 51, 365-379.

Ryan, H. B., Jointer, B. I. \& Ryan, B. I. (1985). MINIT AB Student Handbook, 2nd end. Boston: PWS-Kent.

Skarstad, K., Steen, H. B. \& Boye, E. (1983). Cell cycle parameters of slowly growing Escherichia coli $\mathrm{B} / \mathrm{r}$ studied by flow cytometry. $J$ Bacteriol 154, 656-662.

Sokal, R. R. \& Rohlf, F. J. (1981). Biometry, 2nd edn. San Francisco: W. H. Freeman.

Steen, H. B., Skarsted, K. \& Boye, E. (1990). DNA measurements of bacteria. Methods Cell Biol 33, 519-526. 
Thorsen, B. K., Enger, O., Norland, S. \& Hoff, K. A. (1992). Longterm starvation survival of Yersinia ruckeri at different salinities studied by microscopical and flow cytometric methods. Appl Environ Microbiol 58, 1624-1628.

Tyndall, R. L., Hand, R. E., Jr, Mann, R. C., Evans, C. \& Jernigan, R. (1985). Application of flow cytometry to detection and characterization of Legionella spp. Appl Environ Microbiol 49, 852-857.
Vessy, G., Slade, J. S. \& Fricker, C. R. (1991). Taking the eye strain out of environmental cryptosporidium analysis. Lett Appl Microbiol $13,62-65$.

Received 7 June 1993; revised 15 September 1993; accepted 21 September 1993. 